\title{
Proposal for vaccine lab gets a shot in the arm
}

\section{Jonathan Knight, San Francisco}

The idea of a national vaccine laboratory is gaining momentum in the United States, as advocates of the project pour scorn on the country's ability to produce vaccines. They claim that the recent anthrax attacks have revealed glaring weaknesses in the present system, which effectively relies on drug companies to develop improved vaccines.

But proposals for the new laboratory remain vague. Some suggest that an existing plan for a military vaccine laboratory should be expanded to take a broader role in public health. Another approach would see the Department of Health and Human Services establish a laboratory under the auspices of the National Institutes of Health.

On 5 November, the Institute of Medicine (IOM), which represents leading US physicians and medical researchers, issued a statement calling for a new National Vaccine Authority (NVA). This would develop and stockpile vaccines to meet both military and public-health needs, the IOM suggests. But the IOM has not suggested what it might cost to operate the NVA.

One component of the NVA would be a vaccine laboratory owned by the government but operated by a private contractor, similar in style to the US Department of Energy's existing national laboratory system. Such a facility is described in the 2002 defence authorization bill, which is still being considered by the Congress. But this is only for military use.

The IOM instead advocates building a facility for both public and military purposes. "We think it would be a serious mistake if it were not a dual-use facility for both the military and the public," says the institute's president, Kenneth Shine.

The lab, as Shine envisions it, would develop vaccines that the private sector has little incentive to investigate. The current vaccine for anthrax, for example, requires six injections over 18 months. But without a guaranteed market, pharmaceutical companies might not make the investment needed to research and test a new one, says Shine.

The proposed laboratory would develop and test new vaccines at public expense, and then offer them to drugs companies for manufacture. And for vaccines that are often in short supply, such as that for tetanus, the NVA would consider options such as stockpiling.

Bruce Gellin, director of the National Network For Immunization Information, a Virginia-based group that advocates public vaccination, says a national authority might have the foresight to prevent shortages. In September, stocks of a newly approved vaccine against Streptococcus pneumoniae, which causes respiratory infections in small children that can lead to pneumonia, ran out after the government recommended its use in all children under two years old. "You need to have a place where you could have rational planning and procurement," says Gellin.

But it is the recent fears of bioterrorism that have given new urgency to calls for more government involvement in vaccine development. The crisis has highlighted shortcomings, for example, in US readiness to immunize against smallpox, should this prove necessary. The government last year

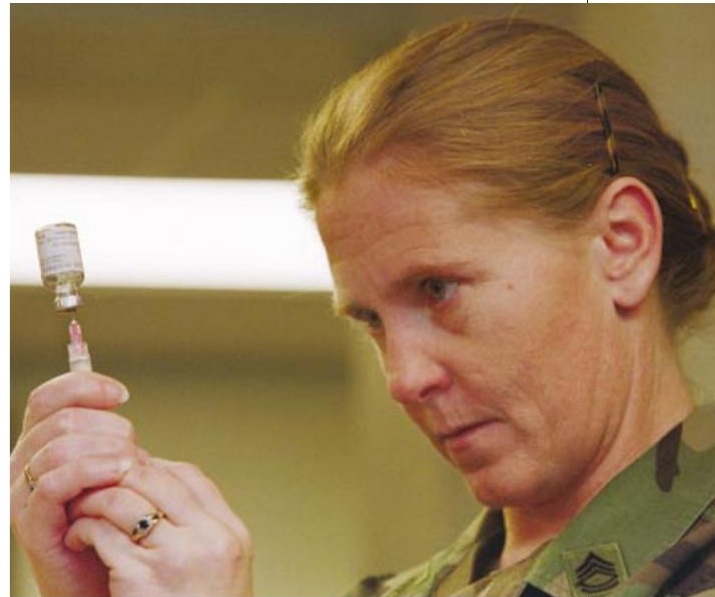

On target: the proposed centre would aim to prevent public shortages of crucial vaccines.

commissioned Acambis, a British pharmaceutical company, to produce 40 million doses of smallpox vaccine over 20 years, and is expected to announce a contract this week for the production of 250 million more.

Shine argues that a vaccine authority could maintain a stockpile to deal with various scenarios. "Given military and terrorism needs, it is likely that something in this area is going to happen," he says.

Other groups have put forward proposals similar to the IOM's. A commission chaired by Republican governor James Gilmore of Virginia, for example, recommended building a similar lab in a 31 October report on responses to terrorist attacks.

www.iom.edu

\section{French Nobel protest makes chemist a cause célèbre}

\section{Sally Goodman, Paris}

France's science minister has written to the director of the Nobel Foundation, Michael Sohlman, protesting that French chemist

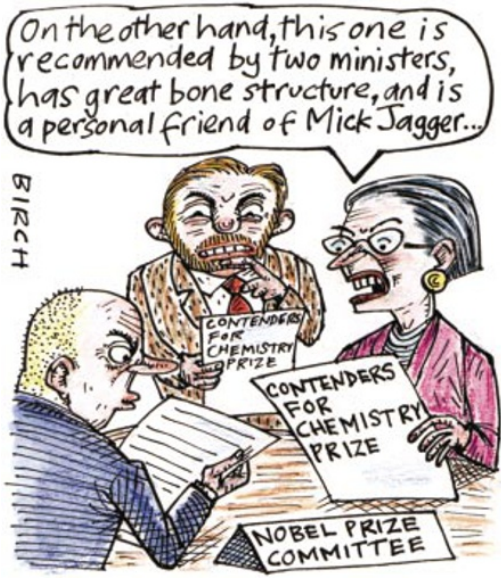

Henri Kagan of Paris-Sud University was not given a share of this year's chemistry prize.

The unusual move by the minister, Roger-Gérard Schwartzenberg, comes after several French scientists voiced their dismay that Kagan missed out.

The coveted prize - which can be shared by no more than three scientists - went to K. Barry Sharpless of the Scripps Research Institute in La Jolla, California, Ryoji Noyori of Nagoya University, Japan, and William Knowles, formerly of Monsanto in St Louis, Missouri, for work on catalytic asymmetric synthesis (see Nature 413, 661; 2001).

The French minister's 5 November letter uses arguments taken from an article by Didier Astruc, an organic chemist at the University of Bordeaux, in Le Monde newspaper. The letter argues that Henri Kagan was the true pioneer in the field of catalytic asymmetric synthesis, citing his 1971 demonstration of the catalytic asymmetric hydrogenation of olefins in which he produced a large excess of one chiral product.

However, the citation issued by the Nobel Foundation in support of the prize names William Knowles as the founding father of catalytic asymmetric hydrogenation, having first demonstrated the process in 1968. But it states that the chiral product he produced at that time "was modest and hardly of any practical use".

In an interview in the newspaper Libération, Léon Ghosez, a chemist from the Catholic University of Leuven in Belgium, denounced the French minister's initiative as "grotesque", adding that the letter would "neither serve the interests of Kagan nor of French chemistry".

Kagan told Nature that he is not behind the science minister's initiative and prefers not to comment on the matter. 